\title{
Growth responses of Chondrus ocellatus Holmes (Gigartinales, Rhodophyta) to two endophytes, Mikrosyphar zosterae Kuckuck (Ectocarpales, Ochrophyta) and Ulvella ramosa (N. L. Gardner) R. Nielsen (Ulvales, Chlorophyta) in culture
}

\author{
Cyr Abel Maranguy Ogandaga ${ }^{1}$, Han Gil Choi ${ }^{1, *}$, Jang Kyun Kim ${ }^{2}$ and Ki Wan Nam ${ }^{3}$ \\ ${ }^{1}$ Faculty of Biological Science and Institute for Environmental Science, Wonkwang University, Iksan 54538, Korea \\ ${ }^{2}$ Department of Marine Science, Incheon National University, Incheon 22012, Korea \\ ${ }^{3}$ Department of Marine Biology, Pukyong National University, Busan 48513, Korea
}

To examine the effects of two endophytic algae, Mikrosyphar zosterae (brown alga) and Ulvella ramosa (green alga), on the host Chondrus ocellatus (red alga), culture experiments were conducted. Four treatments were made: endophytefree (Chondrus only), endophyte- $M$ (Chondrus + Mikrosyphar), endophyte- $U$ (Chondrus + Ulvella), and endophytes-M.U (Chondrus + Mikrosyphar + Ulvella). After 3 weeks, the relative growth rates (RGRs) of frond lengths and the number of newly formed bladelets were examined. M. zosterae formed wart-like dots on C. ocellatus fronds, whereas U. ramosa made dark spots. The RGRs of frond lengths of $C$. ocellatus were significantly greater in the endophyte-free and endophyte- $M$ treatment groups than in the endophyte- $U$ and endophytes- $M \cdot U$ treatment groups, indicating that the growth of host $C$. ocellatus was inhibited more by the green endophyte $U$. ramosa than the brown endophyte $M$. zosterae. The number of newly produced bladelets was greater in the endophyte- $U$ and endophytes- $M \cdot U$ groups than in the endophyte-free and endophyte- $M$ treatment groups. These results indicate that the two endophytes inhibit growth of the host $C$. ocellatus. The negative effects of $U$. ramosa on C. ocellatus growth were more severe than those caused by M. zosterae. Furthermore, U. ramosa destroyed the apical meristems of C. ocellatus, whereas $M$. zosterae did not. On the other hand, C. ocellatus showed compensatory growth in the form of lateral branch production as U. ramosa attacked its apical meristems.

Key words: Chondrus ocellatus; growth; infection; Mikrosyphar zosterae; Ulvella ramosa

\section{INTRODUCTION}

Chondrus, a red algal genus, is an important primary producer providing food and habitat for various marine organisms as many seaweeds do (Lindstrom 2009, Choi et al. 2015a). This alga is also economically important as a major source of carrageenan (Necas and Bartosikova 2013, Zhou et al. 2014). However, natural populations of
Chondrus have declined due to a variety of abiotic (e.g., pollution, ocean acidification, and typhoons) and biotic environmental factors, including predation by herbivores and pathogens (Correa and McLachlan 1992, 1994). Production of natural or cultivated seaweeds has been diminished by seaweed diseases caused by fungi, bacteria,
(1) \$ This is an Open Access article distributed under the terms of the Creative Commons Attribution Non-Commercial License (http://creativecommons.org/licenses/by-nc/3.0/) which permits unrestricted non-commercial use, distribution, and reproduction in any medium, provided the original work is properly cited.
Received October 9, 2016, Accepted December 9, 2016

* Corresponding Author

E-mail: hgchoi@wku.ac.kr

Tel: +82-63-850-6579, Fax: +82-63-857-8837 

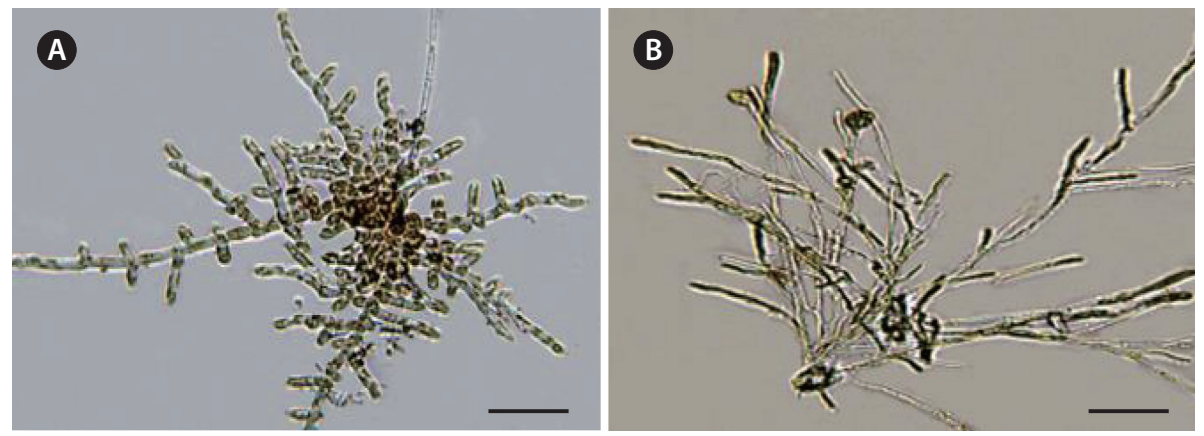

Fig. 1. The two endophytes isolated in laboratory cultures. (A) Mikrosyphar zosterae. (B) Ulvella ramosa. Scale bars represent: A \& B, $50 \mu \mathrm{m}$.

viruses, and endophytic algae (Gachon et al. 2010, Potin 2012, West et al. 2013). Endophytic algae can be infectious and can negatively affect the performance of host seaweeds (Apt 1988, Correa and McLachlan 1992, 1994, Correa et al. 1997). The morphological symptoms of infection with endophytes in host seaweeds include thallus thickening, degradative lesions, cellular damage, gall formation, and morphological deformations (Yoshida and Akiyama 1979, Apt 1988, Correa et al. 1988, 1997, Garbary et al. 2014, Preuss and Zuccarello 2014). The endophytic infection may even reduce the survival, growth, and fertility of host seaweeds (Faugeron et al. 2000, Schoenrock et al. 2013).

Correa and his colleagues conducted intensive studies on endophytes in a red alga, C. crispus (Correa et al. 1988, 1994, Correa and McLachlan 1992, 1994). They found four endophytic species, including three green endophytes, Phaeophila dendroides, Endophyton ramosum (currently regarded as Ulvella ramosa) and U. operculata (previously known as Acrochaete operculata), and one brown endophyte, Streblonema species. Among these endophytes, U. operculata caused depigmentation, cellular disorganization, and wart-like protrusion in C. crispus (Correa et al. 1994). Interestingly, in the presence of $U$. operculata, bacteria accelerated cell wall degradation, resulting in the fragmentation and death of C. crispus (Correa et al. 1988, Correa and McLachlan 1992, 1994). As a protective mechanism, C. crispus gametophytes produced kappacarrageenan oligosaccharides to inhibit infection of endophytic $U$. operculata (Bouarab et al. 2001, Weinberger 2007).

Chondrus ocellatus, which grows on semi-exposed rocky shores, is a bioengineer enhancing species diversity as primary producer and food resources of various marine organisms, and is a potential carrageenophyte in Korea (Kim et al. 2006, Zhou et al. 2014). Lee et al. (2013) reported green endophytes in C. ocellatus, without iden- tifying the species and a green endophytic $U$. ramosa was found in C. ocellatus fronds by Choi et al. (2015b). We also isolated two endophytes, U. ramosa and Mikrosyphar zosterae from C. ocellatus fronds. This study aimed to examine the effects of endophytic U. ramosa and M. zosterae on the growth of their host C. ocellatus, morphological changes of the host seaweed following infection with two infectious endophytes, and the importance of apical growth tips in C. ocellatus.

\section{MATERIALS AND METHODS}

\section{Sampling}

Chondrus ocellatus samples were randomly collected from the low intertidal zone of Manripo, Taean, Korea $\left(36^{\circ} 78^{\prime} \mathrm{N}, 126^{\circ} 8^{\prime} \mathrm{E}\right)$ in July 2015 . The samples were put in labelled plastic bottles, placed in a cooler, and transported to the laboratory. All samples were classified into abnormal fronds with black spots (or wound, and whitening, etc.) as an indication of endophyte infection and healthy fronds with no endophyte infection.

\section{Endophyte isolation, uni-culture, and identifica- tion}

Disc-shaped samples of C. ocellatus fronds with black spots were excised using a cork borer $(1 \mathrm{~cm}$ in diameter). The discs were rinsed for $30 \mathrm{~s}$ with running tap water and immersed in a $0.5 \%$ hypochlorite sodium $(\mathrm{NaClO})$ solution for $30 \mathrm{~s}$ in order to remove microorganisms. The discs were then rinsed several times with autoclaved seawater (Gauna et al. 2009). The discs with black spots were placed in petri dishes (size: $15 \mathrm{~mm} \times 60 \mathrm{~mm}$ ) containing $10 \mathrm{~mL}$ of Provasoli's enriched seawater (PES) medium (Provasoli 1968) and cultured in an incubator at $20^{\circ} \mathrm{C}$ and with 20 
$\mu \mathrm{mol}$ photons $\mathrm{m}^{-2} \mathrm{~s}^{-1}$, and a photoperiod of $12: 12 \mathrm{~h} \mathrm{LD}$ cycle. Light was provided by $40 \mathrm{~W}$ cool-white fluorescent tubes and the level of irradiance was measured using a digital illumination meter (DX-200; INS Enterprise Co., Taipei, Taiwan). The growth of diatoms was inhibited by adding $\mathrm{GeO}_{2}\left(3 \mu \mathrm{g} \mathrm{L}^{-1}\right)$ in culture medium during the first week of cultivation to reduce any negative effects of $\mathrm{GeO}_{2}$ (Fernandes et al. 2011). Filamentous brown M. zosterae and green $U$. ramosa endophytes appeared on the surface of frond discs within 3 to 4 weeks of cultivation. The endophytes were isolated, stock-cultured, and identified as M. zosterae and U. ramosa based on molecular analysis (using the RuBisCo spacer and tufA for the M. zosterae and $U$. ramosa analyses, respectively) and morphological features (Fig. 1A \& B).

\section{Preparation of Chondrus ocellatus juveniles}

Healthy and fertile carposporophytes $(>10 \mathrm{~cm}$ in length) of $C$. ocellatus were cleaned in autoclaved seawater and immersed in $1.5 \% \mathrm{KI}$ solution for $20 \mathrm{~min}$ to remove surface microorganisms without releasing damaged spores (Wang et al. 2006, Li et al. 2010). The fronds were rinsed again several times in the autoclaved seawater, and several hundred frond discs bearing cystocarps were obtained using a cork borer. The discs were dried at room temperature $\left(20^{\circ} \mathrm{C}\right)$ for $1 \mathrm{~h}$ and submerged in autoclaved seawater to induce carpospore release.

Carpospores were inoculated into Petri dishes containing six cut microscope slides $(25 \times 20 \mathrm{~mm})$ and PES medium $(40 \mathrm{~mL})$, and then were left overnight to settle. The following day, the slides bearing sporelings were transferred to a culture dish (size: $40 \mathrm{~mm} \times 100 \mathrm{~mm}$ ) containing 100 $\mathrm{mL}$ of PES medium and $\mathrm{GeO}_{2}\left(3 \mu \mathrm{g} \mathrm{L}^{-1}\right)$. Sporelings were cultured at $20^{\circ} \mathrm{C}, 60 \mu \mathrm{mol}$ photons $\mathrm{m}^{-2} \mathrm{~s}^{-1}$ and $12: 12 \mathrm{~h} \mathrm{LD}$ cycle. The culture medium was replaced weekly.

\section{Endophyte effect on the growth of Chondrus juveniles}

To examine the effects of the endophytes on the growth of C. ocellatus juveniles, 48 C. ocellatus juveniles $(9-11 \mathrm{~mm}$ in length) were prepared. They were allocated into four endophyte treatments, with each endophyte treatment having 12 C. ocellatus juveniles that were placed in plant culture dishes containing $50 \mathrm{~mL}$ of autoclaved seawater each. The endophyte-free treatment (control) had Chondrus juveniles only. Three mixed cultures of endophyte- $M$ (C. ocellatus + M. zosterae), endophyte- $U$ (C. ocellatus + $U$. ramosa), and endophytes- $M \cdot U$ (C. ocellatus $+M$. zos- terae + U. ramosa) were also prepared. Endophyte suspensions were made by mixing the specified endophytes grown in an area of $4 \mathrm{~cm}^{2}$ and blended for $20 \mathrm{~s}$ with 100 $\mathrm{mL}$ of autoclaved seawater. Endophytic species grown in Petri dishes were carefully detached by a blade prior to make endophyte suspension. The Mikrosyphar.Ulvella endophyte suspension was prepared with $U$. ramosa $(2$ $\left.\mathrm{cm}^{2}\right)$ and M. zosterae $\left(2 \mathrm{~cm}^{2}\right)$. For each treatment, an endophyte suspension (100 mL) of M. zosterae, U. ramosa, or Mikrosyphar.Ulvella was inoculated into each plant culture dish containing 12 C. ocellatus juveniles. The control dishes with no endophyte (C. ocellatus juveniles only) were inoculated with $100 \mathrm{~mL}$ autoclaved seawater.

During the 1-week culture period, endophyte- $M$, endophyte- $U$, and endophytes- $M \cdot U$ grew and released zoospores into their respective plant culture dishes. Zoospore release from the experimental endophytes was confirmed under a light microscope using the cut glass slides that had been inserted into the cultures at the beginning of the experiment. After 1 week, 4 C. ocellatus juveniles from the 12 juveniles in each endophyte treatment group were selected and placed into three replicate beakers, each containing $100 \mathrm{~mL}$ of PES medium. The control dishes having 12 C. ocellatus juveniles were also treated like the other endophytic treatments and absence of endophytes was confirmed with the cut glass slides placed on the bottom of the culture dishes. After this, the samples were cultured for 3 weeks at $20^{\circ} \mathrm{C}$ and with 60 $\mu \mathrm{mol}$ photons $\mathrm{m}^{-2} \mathrm{~s}^{-1}$ and a $12: 12 \mathrm{~h} \mathrm{LD}$ cycle. The culture medium was replaced weekly.

All the experimental C. ocellatus juveniles were weekly cleaned by using a paint brush, photographed, and measured in frond length using Image J ver. 1.48 software (National Institutes of Health, Bethesda, MD, USA). We supposed that cleaning activity of the juveniles was influenced with same intensity for endophyte infection and proliferation. New proliferations were counted after 3 weeks. Relative growth rates (RGRs) of fronds (lengths) were estimated by the following formula (Kim et al. 2006):

$$
\operatorname{RGR}\left(\% \mathrm{~d}^{-1}\right)=100 \ln \left(\mathrm{L}_{\mathrm{t}} / \mathrm{L}_{\mathrm{o}}\right) / t
$$

,Where $\mathrm{L}_{0}$ is the initial frond length, $\mathrm{L}_{\mathrm{t}}$ is the final length after $t$ days of cultivation.

Morphological symptoms of infection in host C. ocellatus juveniles were also inspected by the naked eye and under an Olympus BX53 microscope (Olympus, Tokyo, Japan). C. ocellatus tissues, either infected or healthy, were photographed under microscope after semi-thin cryosection. Prior to sectioning, samples were fixed in 

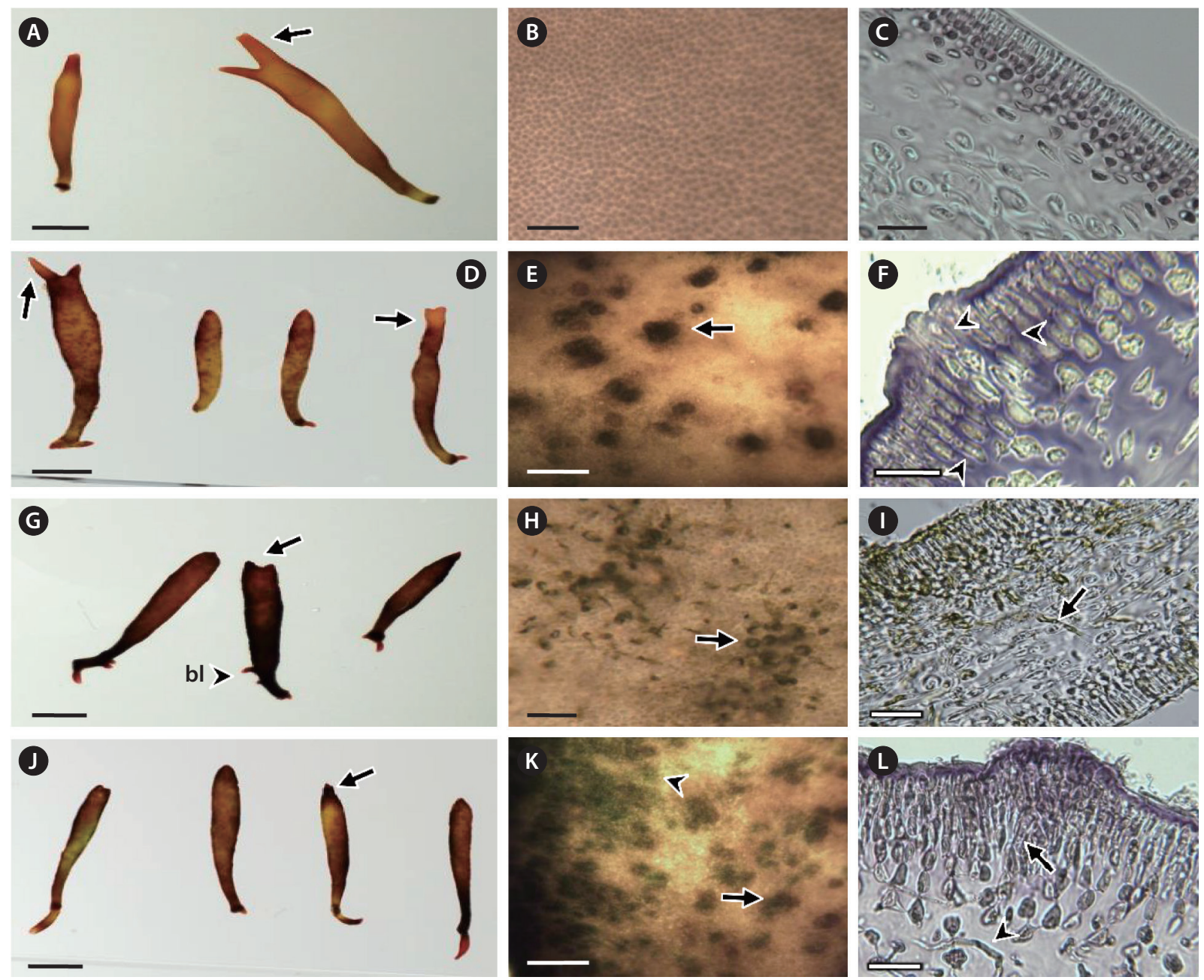

Fig. 2. Morphological symptoms of Chondrus ocellatus juveniles infected with the endophytes Mikrosyphar zosterae and Ulvella ramosa. (A) Non-infected C. ocellatus with healthy apices (arrow). (B) Clean host surface tissues. (C) Cross-sectioned tissues of non-infected C. ocellatus. (D) C. ocellatus juveniles infected with M. zosterae and with healthy apices (arrows). (E) Wart-like spot (arrow) on C. ocellatus surface tissues caused by M. zosterae. (F) M. zosterae filamentous thalli (arrowheads) in cross-sectioned host tissue. (G) C. ocellatus juveniles infected with $U$. ramosa and with coated apices (arrow) and a bladelet (bl) on the host frond. (H) Green patches (arrow) on host surface tissue caused by U. ramosa. (I) U. ramosa filamentous thalli (arrow) in a cross-sectioned host frond. (J) C. ocellatus juveniles infected by U. ramosa and M. zosterae with coated apices (arrow). (K) Green patches (arrowhead) and wart-like spots (arrow) on host tissues. (L) Filamentous thalli of U. ramosa (arrowhead) and M. zosterae (arrow), in cross-sectioned host infected tissues. Scale bars represent: A, D, G \& J, 3 mm; B, $50 \mu \mathrm{m} ; C, H$ \& I, $30 \mu \mathrm{m} ; E$ \& K, $300 \mu \mathrm{m} ; F$ \& L, $20 \mu \mathrm{m}$.

a $10 \%$ formalin-seawater solution and then embedding medium (Tissue-Tek O.C.T. compound; Sakura Finetek USA Inc., Torrance, CA, USA) in a cryochamber at $-30^{\circ} \mathrm{C}$. Sections were made with a Shandon Cryotome Cryostat microtome (Shandon-Thermo Fisher Scientific, Waltham, MA, USA) and stained with a $10 \%$ hematoxylin solution (Mayer's hematoxylin; Dako North America Inc., Carpinteria, CA, USA).

\section{Importance of apical growth tips of Chondrus juveniles}

The endophyte infection experiments showed that $U$. ramosa endophytes infected selectively the apical growth tips of host $C$. ocellatus resulting in the reduction of the growth of C. ocellatus juveniles. Therefore, an additional experiment on the role of apical growth tips in Chondrus juveniles were designed. Twelve C. ocellatus juveniles were divided into apices (from tip to middle) and bases (from middle to base). Twelve intact juveniles, with both apices and bases were used as a control. Three replicate 
beakers for each treatment, containing four C. ocellatus juveniles and $100 \mathrm{~mL}$ of PES medium each, were prepared. The parts of $C$. ocellatus juveniles (apex, base, or intact) were cultured at $20^{\circ} \mathrm{C}$. The irradiance and photoperiod were $60 \mu \mathrm{mol}$ photons $\mathrm{m}^{-2} \mathrm{~s}^{-1}$ and $12: 12 \mathrm{~h} \mathrm{LD}$ cycle, and the culture medium was replaced weekly. Because the C. ocellatus juveniles were so small, total frond weights of each replicate (comprising four juveniles) were measured at the beginning of the experiment and after 3 weeks of cultivation. Frond RGRs (weights) of C. ocellatus juveniles were calculated using the equation shown above. The total number of new proliferations from the four juvenile fronds was also counted.

\section{Data analysis}

A one-way ANOVA was applied to evaluate the effect of endophytes on the RGRs of fronds (lengths) and the number of new proliferations in C. ocellatus juveniles. A oneway ANOVA was also used to examine the effect of apical meristems on the RGRs (frond weight) and the number of new proliferations in C. ocellatus juveniles. Homogeneity of variances was tested using Cochran's test. Tukey's honest significant difference (HSD) test was applied when significant differences between means were detected (Sokal and Rohlf 1995). Statistical analyses were carried out using STATISTICA ver. 7.0 software.

\section{RESULTS}

\section{Symptoms in the infected Chondrus}

C. ocellatus juveniles grew well for 3 weeks, without morphological changes (Fig. 2A-C), in the absence of the brown endophyte $M$. zosterae. When cultured with M. zosterae, host C. ocellatus formed black spots on their fronds except for apical areas (Fig. 2D). C. ocellatus also developed many wart-like spots (Fig. 2E) where endophytic filaments penetrated the cortex of $C$. ocellatus to the upper medulla zone (Fig. 2F). The apical tips of $C$. ocellatus juveniles were coated by $U$. ramosa endophytes (Fig. 2G), and dark green patches were found on the surfaces of whole host fronds (Fig. $2 \mathrm{H}$ ). This green $U$. ramosa endophyte was also found in host tissues (Fig. 2I). In the endophytes- $U \cdot M$ treatment, green patches and wart-like spots were observed on the C. ocellatus fronds (Fig. 2J \& K). Endophytic filaments of both species, $U$. ramosa and M. zosterae, were also observed on fronds and in host tissues (Fig. 2K \& L).

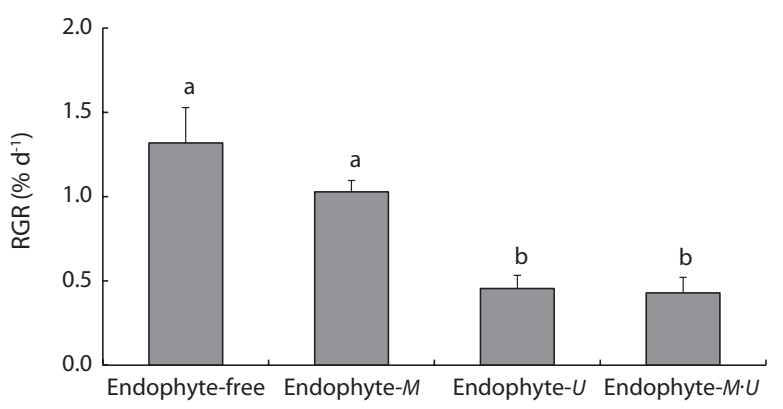

Fig. 3. Relative growth rates (RGRs, frond lengths) of Chondrus ocellatus juveniles, which cultured for 3 weeks in different endophytic treatments (endophyte-free, endophyte- $M$, endophyte- $U$, and endophytes-M.U). Different letters indicate significant differences between the groups determined by Tukey's honest significant difference test. Bars indicate the mean \pm standard error $(n=3)$. Endophyte-free, Chondrus only; endophyte-M, Chondrus + Mikrosyphar; endophyte$U$, Chondrus + Ulvella; endophytes-M.U, Chondrus + Mikrosyphar + Ulvella.

\section{Effects of two endophytes on Chondrus growth}

Chondrus ocellatus juveniles grew with infectious $M$. zosterae or $U$. ramosa, or with both. In 3 weeks of culture after infection, the RGR was significantly greater in the endophyte-free and endophyte- $M$ treatment groups than in the endophyte- $U$ or endophytes- $M \cdot U$ treatment groups (Fig. 3). Interestingly, no differences were found between the endophyte-free and endophyte- $M$ treatment groups, and between the endophyte- $U$ and endophytes$M \cdot U$ treatment groups (Fig. 3), which indicates that the significant negative effects on the growth of host $C$. ocellatus juveniles were attributable to infection with $U$. ramosa.

Three weeks after infection with the endophytes, no C. ocellatus bladelets developed in the endophyte-free and endophyte- $M$ treatment groups, $1.33 \pm 0.33$ (mean \pm standard error [SE], $\mathrm{n}=3$ ) bladelets formed in the endophyte- $U$ treatment group, and $1.67 \pm 0.66(\mathrm{n}=3)$ bladelets formed in the endophytes- $M \cdot U$ treatment group. The number of newly formed bladelets appeared to be significantly greater in the endophyte- $U$ and in the endophytes- $M \cdot U$ treatment groups as compared to the control (endophyte-free) or endophyte- $M$ treatment groups ( $\mathrm{p}<$ $0.05)$. However, no significant differences were found between the endophyte-free and endophyte- $M$ treatment groups and between the endophyte- $U$ and endophytes$M \cdot U$ treatment groups. 


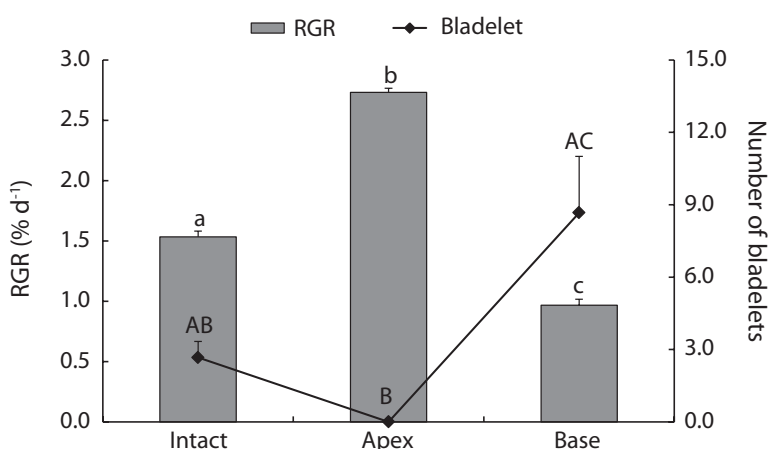

Fig. 4. Relative growth rates (RGRs, frond weights) of Chondrus ocellatus juveniles, and the number of bladelets after 3 weeks of cultivation at three different treatments (intact, apex, and base). Different letters indicate significant differences between the groups determined by Tukey's honest significant difference test. Bars indicate the mean \pm standard error $(n=3)$.

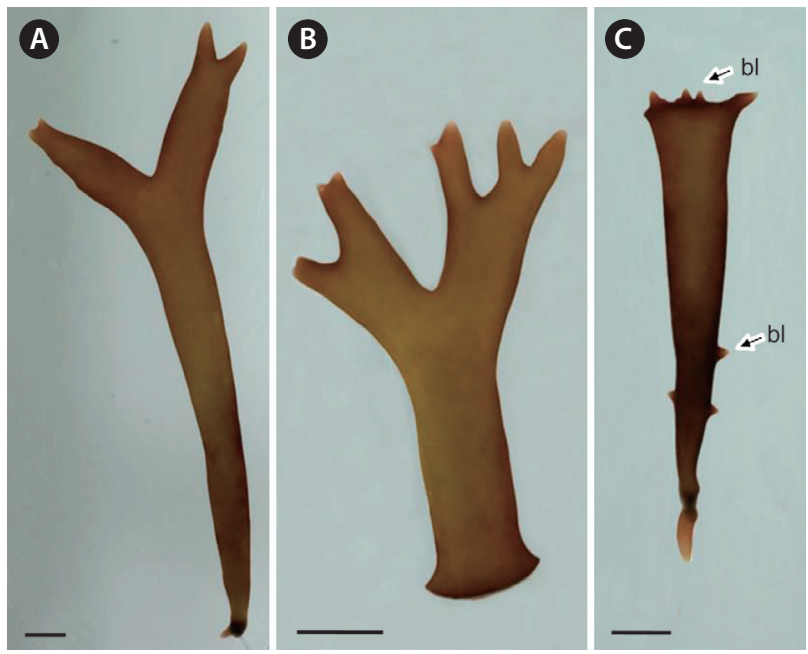

Fig. 5. Growth patterns of Chondrus ocellatus juveniles after 3 weeks in laboratory culture. (A) An intact juvenile as a control. (B) An apex frond without bladelets from a juvenile. (C) A basal frond producing many small bladelets (bl) on the excised part and lateral surface (arrows) of a juvenile frond. Scale bars represent: A-C, $1 \mathrm{~mm}$.

\section{Inportance of apical meristems in Chondrus juveniles}

After 3 weeks of culture, the RGR values (frond weights) of C. ocellatus juveniles ranged from 0.97 to $2.73 \% \mathrm{~d}^{-1}$ (Fig. 4). The values were significantly different between the three treatments, with the highest RGR value in the apex treatment and the lowest in the base treatment (Fig. 4). In addition, the number of newly formed bladelets was significantly different between the treatment groups $(\mathrm{p}<$
0.05). A Tukey's test revealed a significant difference between the apex and base groups, but no differences were found between the intact and apex groups, and between the intact and base groups (Fig. 4). Intact juveniles of $C$. ocellatus produced a few bladelets (Fig. 5A), whereas the apex alone produced no bladelets (Fig. 5B). However, the base of $C$. ocellatus juveniles produced many bladelets in the excised, lateral parts of fronds (Fig. 5C). The number of newly formed C. ocellatus bladelets was $2.67 \pm 0.67$ (mean \pm SE, $n=3$ ) in the intact control and $8.67 \pm 2.33$ ( $\mathrm{n}$ $=3$ ) in the base treatment group. This result indicates that C. ocellatus juveniles grow apically, but that their growth can switch to bladelet production in the absence of apical meristems.

\section{DISCUSSION}

Previous studies have shown that C. crispus harbors endophytes such as brown Streblonema spp. and green $U$. ramosa and U. operculata (Correa et al. 1988). Choi et al. (2015b) recently isolated a green endophyte, U. ramosa, from C. ocellatus. Here, we report that the brown endophyte M. zosterae was present in C. ocellatus. This is the first report of M. zosterae as an endophyte of a carrageenophyte. We also found that morphological symptoms in C. ocellatus of infection with the two endophytes, green $U$. ramosa and brown M. zosterae, were different. $U$. ramosa infection produced dark green patches, whereas M. zosterae infection resulted in wart-like spots. Various green endophytic species in several carrageenophytes induce color changes, form holes, or have other effects on host plants (Table 1).

Although endophytes can cause some morphological changes in seaweeds, the causative organisms forming galls (hyperplasia and hypertrophy in host seaweed cells) on red algal fronds were found to be mostly bacteria, fungi, animals, or viruses (Apt and Gibor 1991, Correa et al. 1993, Goecke et al. 2012). On C. crispus fronds, galls formed in response to nematodes and bacteria (Apt 1988). Another red alga, Iridaea laminarioides (currently regarded as Mazzaella laminarioides) also developed galls on its fronds because of infection with the cyanobacterium Pleurocapsa sp. (Correa et al. 1993). The findings in the present study indicate that infection with the endophyte M. zosterae can also result in the formation of gall-like structures in the red alga C. ocellatus.

In the present study, the infectious endophytes inhibited the growth of host C. ocellatus juveniles, but the degrees of negative effects were different between the endo- 
phytes, M. zosterae and U. ramosa. C. ocellatus juveniles grew significantly better in the endophyte-free $\left(1.32 \% \mathrm{~d}^{-1}\right.$ in RGR) and endophyte- $M$ treatment $\left(1.03 \% \mathrm{~d}^{-1}\right)$ groups than in the endophyte- $U\left(0.45 \% \mathrm{~d}^{-1}\right)$ and endophytes$M \cdot U$ treatment $\left(0.43 \% \mathrm{~d}^{-1}\right)$ groups. In comparison to the RGR values with endophyte-free treatment, the RGR of the host C. ocellatus was reduced by approximately $70 \%$ with endophyte- $U$ treatment. In this condition, $U$. ramosa densely covered the apical meristem tissues of C. ocellatus, perhaps reducing photosynthetic activity.

This study is the first report that the endophyte $U$. ramosa damages apical meristem tissues of $C$. ocellatus juveniles. The growth of $C$. ocellatus was mainly apical, and transverse divisions in apical cells are common. Apical division of C. ocellatus was not observed in the endophyte$U$ treatment or endophytes- $M \cdot U$ treatment groups (Fig. 2). This resulted in a significant reduction in the RGRs in these conditions. Removal of apical meristems from $C$. ocellatus juveniles reduced growth by $37 \%$ compared to that in the intact treatment group and by $65 \%$ compared to that in the apex treatment group. This result implies the importance of apical meristems to the growth of $C$. ocellatus. Previously, C. crispus were shown to grow three times more in apical meristems than in other parts of the organism (Chopin and Floc'h 1992).

Interestingly, defects in the apical meristems of C. ocellatus resulted in the formation of bladelets. Surface and marginal proliferations are commonly observed in adultstage reproductive organs in Chondrus species, including
C. nipponicus and C. ocellatus (Brodie et al. 1991, 1993). In this study, we found that C. ocellatus, even in the juvenile stage, produced small bladelets $(\leq 2.1 \mathrm{~mm}$ in length) in the absence of apical growth tips or with apical tissue damaged by $U$. ramosa. Formation of many bladelets in the damaged fronds or in the basal fronds of C. ocellatus may be a mechanism to compensate for the lack of growth in the removed apical meristems. Similarly, Fucus vesiculosus produced many lateral branches that served as new apical meristems when their apices were damaged (Honkanen and Jormalainen 2002). Chondrus crispus was also shown to produce many bladelets (Corey et al. 2012). Corey et al. (2012) reported that bladelet development in C. crispus was more pronounced at temperatures of $17^{\circ} \mathrm{C}$ or above, and high temperatures may be optimal for the growth of the green endophyte U. operculata or U. ramo$s a$, or both (Correa et al. 1988).

Here, we reported M. zosterae as a new endophyte of $C$. ocellatus. What we do not know is the level of host-specificity of M. zosterae. Although M. zosterae formed wartlike spots on C. ocellatus, this endophyte did not cause significant negative effects on the growth of the host alga. Therefore, there is a need to analyze more seaweed species, especially carrageenophytes to determine the hostspecificity of M. zosterae. It is also important to determine whether different life stages of $C$. ocellatus respond differently to these endophytes, because some endophytes (e.g., $U$. operculata) affect the sporophytic fronds of $C$. crispus more severely than its gametophytes (Correa and

Table 1. Morphological symptoms of carrageenophytes in response to infection with a variety of green endophytic algae

\begin{tabular}{|c|c|c|c|}
\hline Host seaweed & Endophyte & Symptom & Reference \\
\hline Grateloupia sp. & Blastophysa rhizopus & Green spot rotting & Iima and Tatewaki (1987) \\
\hline Chondrus crispus & $\begin{array}{l}\text { Acrochaete operculata, } \\
\text { Acrochaete heteroclada, } \\
\text { Phaeophila dendroides }\end{array}$ & $\begin{array}{l}\text { Dark patches } \\
\text { Lesions } \\
\text { Tissue softening }\end{array}$ & Correa et al. (1988) \\
\hline Iridaea cordata & $\begin{array}{l}\text { Acrochaete heteroclada } \\
\text { Acrochaete operculata }\end{array}$ & $\begin{array}{l}\text { Dark patches } \\
\text { Lesions } \\
\text { Tissue softening }\end{array}$ & Correa and McLachlan (1991) \\
\hline $\begin{array}{l}\text { Iridaea laminarioides } \\
\text { Mazzaella laminarioides } \\
\text { Chondrus crispus } \\
\text { Rhodoglossum califonicum } \\
\text { Erythrodremis traillii } \\
\text { Phyllophora pseudoceranoides } \\
\text { Ahnfeltiopsis devoniensis } \\
\text { A. furcellata }\end{array}$ & $\begin{array}{l}\text { Endophyton sp. } \\
\text { Endophyton ramosum }\end{array}$ & $\begin{array}{l}\text { Green patches } \\
\text { Dark green } \\
\text { Lesions } \\
\text { Tissue softening } \\
\text { Discoloration } \\
\text { Cell necrosis }\end{array}$ & $\begin{array}{l}\text { Correa et al. (1994) } \\
\text { Sánchez et al. (1996) }\end{array}$ \\
\hline Grateloupia lanceolata & $\begin{array}{l}\text { Ulvella eptochaete, } \\
\text { Blastophysa rhizopus, } \\
\text { Bolbocoleon piliferum }\end{array}$ & $\begin{array}{l}\text { Light-green spots, } \\
\text { Hole formation, } \\
\text { Discoloration } \\
\text { Cell necrosis }\end{array}$ & Kim et al. (2014) \\
\hline
\end{tabular}

Acrochaete operculata = Ulvella operculata, Acrochaete heteroclada = Ulvella heteroclada, Endophyton ramosum = Ulvella ramosa. 
McLachlan 1994). The endophytes found in this study, $M$. zosterae and $U$. ramosa, are pathogens of C. ocellatus that result in distinctive symptoms, and, in the case of $U$. ramosa, decrease growth of the host seaweed by damaging meristem tissues.

\section{ACKNOWLEDGEMENTS}

We would like to thank anonymous reviewers for helpful comments that improved the manuscript. This paper was supported by Wonkwang University in 2014.

\section{REFERENCES}

Apt, K. E. 1988. Galls and tumor-like growths on marine macroalgae. Dis. Aquat. Org. 4:211-217.

Apt, K. E. \& Gibor, A. 1991. The ultrastructure of galls on the red alga Gracilaria epihippisora. J. Phycol. 27:409-413.

Bouarab, K., Potin, P., Weinberger, F., Correa, J. \& Kloareg, B. 2001. The Chondrus crispus-Acrochaete operculata hostpathogen association, a novel model in glycobiology and applied phycopathology. J. Appl. Phycol. 13:185-193.

Brodie, J., Guiry, M. D. \& Masuda, M. 1991. Life history and morphology of Chondrus nipponicus (Gigartinales, Rhodophyta) from Japan. Br. Phycol. J. 26:33-50.

Brodie, J., Guiry, M. D. \& Masuda, M. 1993. Life history, morphology and crossability of Chondrus ocellatus forma ocellatus and C. ocellatus forma crispoides (Gigartinales, Rhodophyta) from the north-western Pacific. Eur. J. Phycol. 28:183-196.

Choi, H. G., Kim, B. Y., Park, S. K., Heo, J. S., Kim, C., Kim, Y. S. \& Nam, K. W. 2015a. Effects of wave action and grazers on frond perforation of the green alga, Ulva australis. Algae 30:59-66.

Choi, H. G., Kim, C., Kim, Y. S., Lee, S, J., Park, M. A. \& Nam, K. W. 2015b. Phenology of host Chondrus ocellatus with filamentous green endophyte infection. Ocean Sci. J. 50:519-527.

Chopin, T. \& Floc'h, J. -Y. 1992. Eco-physiological and biochemical study of two of the most contrasting forms of Chondrus crispus (Rhodophyta, Gigartinales). Mar. Ecol. Prog. Ser. 81:185-195.

Corey, P., Kim, J. K., Garbary, D. J., Prithiviraj, B. \& Duston, J. 2012. Bioremediation potential of Chondrus crispus (Basin Head) and Palmaria palmata: effect of temperature and high nitrate on nutrient removal. J. Appl. Phycol. 24:441-448.

Correa, J. A., Buschmann, A., Retamales, C. \& Beltrán, J. 1997.
Infectious diseases of Mazzaella laminarioides (Rhodophyta): changes in infection prevalence and disease expression associated with season, locality, and withinsite location. J. Phycol. 33:344-352.

Correa, J. A., Flores, V. \& Garrido, J. 1994. Green patch disease in Iridaea laminarioides (Rhodophyta) caused by Endophyton sp. (Chlorophyta). Dis. Aquat. Org. 19:203-213.

Correa, J. A., Flores, V. \& Sánchez, P. 1993. Deformative disease in Iridaea laminarioides (Rhodophyta): gall development associated with an endophytic cyanobacterium. J. Phycol. 29:853-860.

Correa, J. A. \& McLachlan, J. L. 1991. Endophytic algae of Chondrus crispus (Rhodophyta). III. Host-specificity. J. Phycol. 27:448-459.

Correa, J. A. \& McLachlan, J. L. 1992. Endophytic algae of Chondrus crispus (Rhodophyta). IV. Effects on the host following infections by Acrochaete operculata and A. heteroclada (Chlorophyta). Mar. Ecol. Prog. Ser. 81:73-87.

Correa, J. A. \& McLachlan, J. L. 1994. Endophytic algae of Chondrus crispus (Rhodophyta). V. Fine structure of the infection by Acrochaete operculata (Chlorophyta). Eur. J. Phycol. 29:33-47.

Correa, J. A., Nielsen, R. \& Grund, D. W. 1988. Endophytic algae of Chondrus crispus (Rhodophyta) II. Acrochaete heteroclada sp. nov., A. operculata sp. nov., and Phaeophila dendroides (Chlorophyta). J. Phycol. 24:528-539.

Faugeron, S., Martínez, E. A., Sánchez, P. A. \& Correa, J. A. 2000. Infectious diseases in Mazzaella laminarioides (Rhodophyta): estimating the effect of infections on host reproductive potential. Dis. Aquat. Org. 42:143-148.

Fernandes, D. R. P., Yokoya, N. S. \& Yoneshigue-Valentin, Y. 2011. Protocol for seaweed decontamination to isolate unialgal cultures. Rev. Bras. Farmacogn. 21:313-316.

Gachon, C. M. M., Sime-Ngando, T., Strittmatter, M., Chambouvet, A. \& Kim, G. H. 2010. Algal diseases: spotlight on a black box. Trends Plant Sci. 15:633-640.

Garbary, D. J., Miller, A. G. \& Scrosati, R. A. 2014. Ascophyllum nodosum and its symbionts: XI. The epiphyte Vertebrata lanosa performs better photosynthetically when attached to Ascophyllum than when alone. Algae 29:321331.

Gauna, M. C., Parodi, E. R. \& Cáceres, E. J. 2009. Epi-endophytic symbiosis between Laminariocolax aecidioides (Ectocarpales, Phaeophyceae) and Undaria pinnatifida (Laminariales, Phaeophyceae) growing on Argentinian coasts. J. Appl. Phycol. 21:11-18.

Goecke, F., Wiese, J., Núñez, A., Labes, A., Imhoff, J. F. \& Neuhauser, S. 2012. A novel phytomyxean parasite associated with galls on the bull-kelp Durvillaea antarctica (Chamisso) Hariot. PLoS One 7:e45358. 
Honkanen, T. \& Jormalainen, V. 2002. Within-alga integration and compensation: effects of simulated herbivory on growth and reproduction of the brown alga, Fucus vesiculosus. Int. J. Plant Sci. 163:815-823.

Iima, M. \& Tatewaki, M. 1987. On the life history and host specificity of Blastophysa rhizopus (Codiales, Chaetosiphonaceae), an endophytic green alga from Mororan in laboratory cultures. Jpn. J. Phycol. 35:241-250.

Kim, C., Kim, Y. S., Choi, H. G. \& Nam, K. W. 2014. New records of three endophytic green algae from Grateloupia spp. (Rhodophyta) in Korea. Algae 29:127-136.

Kim, Y. S., Choi, H. G. \& Nam, K. W. 2006. Phenology of Chondrus ocellatus in Cheongsapo near Busan, Korea. J. Appl. Phycol. 18:551-556.

Lee, S. J., Park, M. -A., Ogandaga-Maranguy, C. A., Park, S. K., Kim, H., Kim, Y. S. \& Choi, H. G. 2013. A study on the growth and disease of Chondrus ocellatus in Korea. J. Fish Pathol. 26:265-274.

Li, X., Zhao, P., Wang, G., Li, D., Wang, J. \& Duan, D. 2010. Effects of temperature and irradiance on early development of Chondrus ocellatus Holm (Gigartinaceae, Rhodophyta). Chin. J. Oceanol. Limnol. 28:508-513.

Lindstrom, S. C. 2009. The biogeography of seaweeds in southeast Alaska. J. Biogeogr. 36:401-409.

Necas, J. \& Bartosikova, L. 2013. Carrageenan: a review. Vet. Med. Czech. 58:187-205.

Potin, P. 2012. Intimate Associations between epiphytes, endophytes, and parasites of seaweeds. In Wiencke, C. \& Bischof, K. (Eds.) Seaweed Biology: Novel Insights into Ecophysiology, Ecology and Utilization. Springer, NY, pp. 203-234.

Preuss, M. \& Zuccarello, G. C. 2014. What's in a name? Monophyly of genera in the red algae: Rhodophyllis parasitica sp. nov. (Gigartinales, Rhodophyta); a new red algal par- asite from New Zealand. Algae 29:279-288.

Provasoli, L. 1968. Media and prospects for the cultivation of marine algae. In Watanabe, A. \& Hattori, A. (Eds.) Cultures and Collections of Algae. Proc. U. S. Jpn. Conf. 1966, Japanese Society for Plant Physiology, Hakone, pp. 6375.

Sánchez, P. C., Correa, J. A. \& Garcia-Reina, G. 1996. Hostspecificity of Endophyton ramosum (Chlorophyta), the causative agent of green patch disease in Mazzaella laminarioides (Rhodophyta). Eur. J. Phycol. 31:173-179.

Schoenrock, K. M., Amsler, C. D., McClintock, J. B. \& Baker, B. J. 2013. Endophyte presence as a potential stressor on growth and survival in Antarctic macroalgal hosts. Phycologia 52:595-599.

Sokal, R. R. \& Rohlf, F. J. 1995. Biometry: the principles and practices of statistics in biological research. 3rd ed. W. $\mathrm{H}$. Freeman, NY, 887 pp.

Yoshida, T. \& Akiyama, K. 1979. Streblonema (Phaeophyceae) infection in the frond of cultivated Undaria (Phaeophyceae). In Proc. 9th Int. Seaweed Symp., Science Press, Santa Barbara, CA, pp. 219-223.

Wang, A., Wang, J. \& Duan, D. 2006. Early development of Chondrus ocellatus Holm (Gigartinaceae, Rhodophyta). Chin. J. Oceanol. Limnol. 24:129-133.

Weinberger, F. 2007. Pathogen-induced defense and innate immunity in macroalgae. Biol. Bull. 213:290-302.

West, J. A., Pueschel, C. M., Klochkova, T. A., Kim, G. H., de Goër, S. \& Zuccarello, G. C. 2013. Gall structure and specificity in Bostrychia culture isolated (Rhodomelaceae, Rhodophyta). Algae 28:83-92.

Zhou, G., Ma, W. \& Yuan, P. 2014. Chemical characterization and antioxidant activities of different sulfate content of $\lambda$-carrageenan fractions from edible red seaweed Chondrus ocellatus. Cell. Mol. Biol. 60:107. 